\title{
HISTORYCZNO-PRAWNE UWARUNKOWANIA UTWORZENIA PRZEZ HENRYKA VIII ANGIELSKIEGO KOŚCIOLA PAŃSTWOWEGO W 1534 R.
}

Gdyby przyjrzeć się historii początków reformacji w Anglii, można dość łatwo zauważyć, że w przeciwieństwie do wydarzeń, jakie miały miejsce w Niemczech, próżno jej przyczyn szukać w „szkodliwej” działalności humanistów czy też w negatywnym nastawieniu społeczeństwa do duchowieństwa i hierarchii kościelnej. Trudno również szukać wśród społeczeństwa angielskiego radykalnych postaw antypapieskich, za wyjątkiem epizodu związanego z działalnością Jana Wycliffa ${ }^{1}$. Należy mieć za to na uwadze specyficzny charakter angielskiego Kościoła katolickiego, cechującego się dużą autonomią względem papieża. Mowa tutaj przede wszystkim o zakresie władzy, jaki nad lokalnym Kościołem posiadał władca, a także o jego prerogatywach względem obsadzania stolic biskupich w prowincjach York i Canterbury. W historii Anglii zdarzały się okresy, w których królowie i papieże toczyli spory, jednak u progu nowożytności wydawało się, że jest to kwestia dawno zamknięta i owe wzajemne niesnaski nie powinny się więcej powtórzyć, ponieważ każda z dwóch władz dążyła raczej do tego, by zachować status quo. Dlatego też tym ciekawszy jest fakt, że rozbrat z Kościołem katolickim dokonał się w Anglii z przyczyn o wiele bardziej prozaicznych, podyktowanych namiętnością i chęcią posiadania następcy tronu płci męskiej oraz uwarunkowanych wydarzeniami mającymi miejsce we wcześniejszych stuleciach niż sensu stricto z chęci reformy Kościoła ${ }^{2}$. Istotną rzeczą jest również zwrócenie uwagi na to, że Kościół państwowy, na którego czele stanął Henryk, nie był jeszcze tym, co powszechnie zwykło nazywać się anglikanizmem lub Kościołem anglikańskim. O wiele bardziej zasadne wydaje się być zatem stosowanie sformułowania angielski Kościół państwowy lub państwowy Kościół Anglii. Określenia te zdaniem autora precyzyjnej oddają istotę nowo powstałego Kościoła.

\footnotetext{
* Mgr Tomasz Grzebyk - absolwent, a obecnie doktorant historii na Uniwersytecie Rzeszowskim, na którym ukończył również studia z zakresu administracji. Swoje zainteresowania badawcze koncentruje wokół historii Anglii w XVI i I poł. XVII wieku, relacji polsko-angielskich w tym okresie oraz dziejów Kościoła katolickiego w Anglii za rządów Elżbiety I i pierwszych Stuartów. Interesuje się również zagadnieniami dotyczącymi relacji historii z kinematografią. E-mail: grzebykt@gmail.com.

1 Jan Wycliffe (1329-1384) - angielski teolog, duchowny i reformator; profesor teologii na Uniwersytecie w Oxfordzie.

2 C.W. Dugmore, The Mass and the English Reformers, London 1958, s 83-84; B. Kumor, Historia Kościoła, t. 5: Czasy nowożytne. Rozłam w chrześcijaństwie zachodnim, Lublin 2004, s. 80-81.
} 


\section{Przyczyny wysokiej pozycji władców w Kościele katolickim w Anglii we wczesnym średniowieczu}

Wczesnośredniowieczna struktura organizacyjna Kościoła katolickiego w Anglii, której twórcą był św. Augustyn z Canterbury i jego następcy, została w dużej mierze zniszczona na skutek najazdów Normanów. Jej odbudowa na przełomie VIII i IX w. to zasługa władców krain takich jak Mercja, Wessex czy Northumbia, którzy dzięki swojej hojności i otaczaniu opieką klasztorów oraz parafii zdobyli wysoką pozycję wśród chrześcijan zamieszkujących ówczesną Anglię? . Przyjmując chrześcijaństwo, uzyskiwali oni wiele przywilejów, ale również i obowiązków w kwestiach związanych z religią. Władca pełnił rolę mecenasa nie tylko kultury, będącej wówczas domeną Kościoła, ale również fundował klasztory i kościoły oraz brał je na utrzymanie skarbca królewskiego. Jednocześnie królowie tacy jak Alfred Wielki ${ }^{4}$ czy Edgar I5 dzierżyli prawo utrzymywania ładu społeczno-religijnego, stojąc na czele sądów zajmujących się walką z kultami pogańskimi i czarnoksięstwem ${ }^{6}$.

Wraz ze wzrostem znaczenia pozycji monarchy w stosunku do hierarchii Kościoła katolickiego w Anglii coraz bardziej widoczny stawał się rozdźwięk pomiędzy interesami władzy świeckiej i władzy duchownej. Kresu temu procesowi nie położyła inwazja normandzka w I066 r. Co więcej, centralizacja władzy, jakiej poddana została Anglia za panowania Wilhelma I Zdobywcy7 , powodowała, iż król mógł rościć sobie prawo do zwierzchnictwa nad Kościołem w swoim państwie, co w zasadniczym elemencie sporu nie różniło się znacznie od problemu, z jakim borykała się cała ówczesna Europa, a mianowicie ze sporem o inwestyturę. Problemu nie rozwiązała również reforma gregoriańska, która w królestwie Anglii została przeprowadzona w sposób zdecydowanie konserwatywny, co oznaczało m.in.: utrzymanie prawa królewskiego do nadawania stanowisk biskupich oraz zatwierdzanie uchwał synodów. Jednakże, pomimo tego, polityka, jaką prowadził Wilhelm, pozwalała na nieskrępowane relacje pomiędzy hierarchią kościelną a Rzymem oraz pewną autonomię w zakresie prawa i majątku kościelnego.

\section{Próby ingerencji królów angielskich w sprawy Kościoła katolickiego w okresie sporów o inwestyturę}

Idea papieża Grzegorza VII ${ }^{8}$ dotycząca sprawowania przez głowę Kościoła katolickiego uniwersalistycznej władzy nad całym światem chrześcijańskim oraz specyfika relacji Kościoła angielskiego z władzą świecką tego kraju prowadziły do nierzadko radykalnych w swojej formie konfliktów 9 . Pierwszy z nich toczył się pomiędzy arcybiskupem Canterbury - Anzel-

\footnotetext{
3 Nie było to zjawisko zupełnie nowe, gdyż już podczas synodu w Whitby znaczącą rolę odegrał król Northumbii-Osiwu.

4 Alfred Wielki (849-899) - syn Aethelwulfa, szósty król Wesseksu, niekiedy uważany za pierwszego historycznego władcę zjednoczonej Anglii; panował w latach 871-899.

5 Edgar I (943-975) - syn Edmunda Starszego i św. Elgivy, król Anglii w latach 959-975.

6 J.R.H. Moorman, The History of the Church in England, Harrisburg 1980, s. 42; B. Kumor, Historia Kościola, t. 2: Wczesne średniowiecze chrześcijańskie, Lublin 2003, s. 99.

7 Wilhelm I Zdobywca (1028-1087) - syn Roberta I i Herlevy, książę Normandii i władca Anglii w latach 10661087; z racji pochodzenia z nieprawego łoża zwany także Wilhelmem Bękartem.

8 Grzegorz VII (1020-1085) - właściwie Hildebrand OSB, reformator Kościoła i papież w latach 1073-1085; święty.

9 B. Kumor, Historia Kościoła, t. 3: Ztoty okres średniowiecza chrześcijańskiego, Lublin 2005, s. 40-41.
} 
mem $^{\mathrm{IO}}$ a Wilhelmem II ${ }^{\mathrm{II}}$, a dotyczył kwestii związanych z majątkiem kościelnym i był próbą zagarnięcia go przez króla. Następstwem sporu była ucieczka Anzelma do Francji w I097 r. Biskup powrócił do Albionu za panowania Henryka $\mathrm{I}^{12}$, lecz wkrótce znowu musiał opuścić Anglię ze względu na ponowne zaostrzenie konfliktu wyrażające się tym razem poprzez żądanie złożenia przez biskupów angielskich przysięgi lennej królowi. Dopiero ingerencja papieża Paschalisa II ${ }^{13}$ doprowadziła w IIO7 r. do zawarcia porozumienia, wedle którego król zrzekał się prawa do inwestytury. Nie przetrwało ono jednak zbyt długo, gdyż krótko po śmierci Anzelma król zakazał hierarchii kościelnej kontaktów z Rzymem ${ }^{14}$.

Za apogeum konfliktów pomiędzy władzą świecką a duchowną, jakie dotykały Kościół katolicki w Anglii w XII i XIII stuleciu, uważa się spór pomiędzy arcybiskupem Canterbury - Tomaszem Becketem ${ }^{15}$ a królem Henrykiem II Plantagenetem ${ }^{16}$. Jego podłożem stało się uchwalenie tzw. konstytucji klaredońskich w II64 r., których celem było przejęcie władzy nad Kościołem poprzez wpływ na wybór biskupów wskazywanych przez króla oraz przekazanie części spraw sądów kościelnych sądom świeckim. Ponadto w powyższym dokumencie Henryk II zakazywał odwoływania się biskupom do sądu w Rzymie. Postanowieniom tym jawnie sprzeciwił się Tomasz Becket, odwołując się do postulatów reformy gregoriańskiej oraz wypracowanych wcześniej kompromisów. W odpowiedzi król Anglii wypędził arcybiskupa z kraju, lecz dzięki mediacji papieża Aleksandra III $^{17}$ i króla Francji Ludwika VII ${ }^{18}$ konflikt załagodzono i Tomasz mógł ponownie wrócić na swoją stolicę biskupią, skąd jednak musiał wkrótce ponownie uciekać do Francji. Do kraju rządzonego przez Henryka II powrócił w II70 r. Niedługo potem został zamordowany przez czterech rycerzy przy ołtarzu katedry w Canterbury podczas odprawiania nieszporów ${ }^{19}$.

Śmierć Becketa odbiła się w Europie głośnym echem i przyniosła Henrykowi II niesławę. Bunt, jaki podniosło przeciw niemu duchowieństwo angielskie i część feudałów, oraz zagrożenie ekskomuniką, jakie wysunął przeciw niemu Aleksander III, spowodowały, że rok po kanonizacji Tomasza Becketa, w II74 r. król Anglii odbył publiczną pokutę oraz uchylił niektóre z postanowień klaredońskich, pozostawiając jednak dla siebie wpływ na obsadę biskupstw. Król zobowiązał się również przestrzegać zasady apelacji od wyroku sądowego do Rzymu, w praktyce jednak wnioski te rozpatrywał specjalny sędzia papieski rezydujący w Angliii ${ }^{20}$. Choć sprawa morderstwa Tomasza Becketa i jego następstwa nie spowodowały, że

\footnotetext{
10 Anzelm z Canterbury (1033-1109) - benedyktyn, arcybiskup Canterbury w latach 1093-1109; uważany za twórcę scholastyki; święty i doktor Kościoła.

11 Wilhelm II (1056-1100) - syn Wilhelma I Zdobywcy i Matyldy Flandryjskiej, król Anglii w latach 1087-1100.

12 Henryk I (1068-1135) - najmłodszy syn Wilhelma I Zdobywcy i Matyldy Flandryjskiej, król Anglii w latach 1100-1135.

13 Paschalis II (1053/55-1118) - właściwie Rainierus OSB, papież w latach 1099-1118.

14 M.D. Knowles, D. Obolensky, Historia Kościoła, t. 2, tłum. R. Turzyński, Warszawa 1988, s. 155-156.

15 Tomasz Becket (1118-1170) - arcybiskup Canterbury w latach 1162-1170, kanclerz Anglii w latach 1155-1162; męczennik i święty.

16 Henryk II Plantagenet (1133-1189) - syn Godfryda V Plantageneta i Matyldy, córki Stefana z Blois; król Anglii w latach 1154-1189.

17 Aleksander III (1100-1181) - właściwie Rolando Bandinelli; papież w latach 1159-1181.

18 Ludwik VII (1120-1180) - syn Ludwika VI i Adelajdy z Maurienne, król Francji w latach 1137-1180.

19 J.R.H. Moorman, op. cit., s. 81; B. Kumor, Historia Kościoła, t. 3, op. cit., s. 42.

20 R. Barber, The Devil's Crown. A History of Henry II and His Sons, Conshohocken 1996, s. 193-195.
} 
spory pomiędzy władcami Anglii a Kościołem zniknęły całkowicie, to do czasu panowania Henryka VIII nie przybrały już one tak dramatycznego w skutkach obrotu.

\section{Kwestia upaństwowienia Kościoła w Anglii w prawodawstwie królewskim u schylku średniowiecza}

Monarchowie władający Anglią w XIII i XIV w. starali się dbać o właściwe relacje z duchowieństwem, dowodem na to wydaje się być zapis, jaki można znaleźć w Magna Charta Libertatum (Wielka Karta Swobód). Już na wstępie zawiera ona następujące sformułowanie: „Po pierwsze, przyznajemy Bogu i potwierdzamy mocą niniejszego dokumentu, że Kościół angielski powinien być suwerenny, zaś jego prawa i wolności powinny zostać nienaruszalne ani przez nas, ani przez naszych następców, po wieki wieków"² . Co jednak wydaje się istotne, a poniekąd również frapujące w kontekście dalszych wydarzeń prowadzących do powstania angielskiego Kościoła państwowego, to pojawiająca się tutaj sugestia, jakoby „Kościół angielski” był organizmem niezależnym nie tyle od władzy króla, co odrębnym od Kościoła katolickiego. Jednak pomimo tych deklaracji, kwestia tego, komu powinna podlegać hierarchia katolicka w Anglii, pozostała de facto nierozwiązana.

Czternaste stulecie przyniosło w tym względzie jedno niezwykle istotne wydarzenie. Było nim wydanie w 1392 r. Statute of Praemunire (Ustawa o wzmocnieniu), poprzedzone opublikowaniem Statute of Provisors (Ustawa o beneficjach) w I35I r. Obydwie ustawy były wymierzone w zakres jurysdykcji papieskiej na terenie królestwa Anglii, lecz o ile ustawa o beneficjach dotyczyła kwestii materialnego uzależnienia duchowieństwa, to ustawa o wzmocnieniu była wprost skierowana na podporządkowanie hierarchii kościelnej interesom króla. Olbrzymim novum Ustawy o wzmocnieniu było to, że - oprócz znanych z wcześniejszej historii Anglii zagadnień związanych z zakazem odwoływania się do papieża od wyroków wydanych przez sądy królewskie - poruszała kwestię nadrzędności władzy króla względem papieża, szczególnie w zakresie nadawania beneficjów, ale również w zakresie wszelkich spraw, które mogłyby być działaniami prowadzonymi na niekorzyść królestwa ${ }^{22}$.

Nieco inne światło na próbę upaństwowienia Kościoła katolickiego w Anglii rzuca natomiast kwestia ustawy De haeretico comburendo (O paleniu heretyków). W związku z działalnością lollardów, dzięki staraniom arcybiskupa Canterbury - Tomasza Arundela ${ }^{23}$, w I4OI r. król Henryk IV ${ }^{24}$ zdecydował się przeforsować w parlamencie prawo stanowiące, że każda osoba skazana przez sąd kościelny za herezję, która nie wyrzekła się swoich poglądów, powinna być wydana władzy świeckiej oraz podlegać śmierci poprzez spalenie na stosie ${ }^{25}$. Posunięcie to, choć powinno świadczyć o wzorowej wręcz współpracy króla i duchowieństwa w zakresie utrzymania porządku społecznego, w realiach angielskich miało swoiste „drugie dno” mówiące o niesłabnącej chęci królewskiej dominacji nad Kościołem w Anglii.

\footnotetext{
${ }^{21}$ Magna Carta, The Great Charter of English liberty granted (under considerable duress) by King John at Runnymede on June 15, 1215, http://www.britannia.com/history/docs/magna2.html (dostęp: 12.11.2017).

22 J.H. Dahmus, Richard II and the Church, „Catholic Historical Review”, 39/1954, s. 410-411.

23 Tomasz Arundel (1364-1414) - arcybiskup Canterbury w latach 1397, 1399-1414.

24 Henryk IV (1367-1413) - syn Jana z Gandawy i Blanki, król Anglii w latach 1399-1413.

25 The Oxford Dictionary of the Christian Church, edited by F. L. Cross, E. A. Livingstone, Current Online Version 2009, http://www.oxfordreference.com/view/10.1093/acref/9780192802903.001.0001/acref-9780192802903 (dostęp: 14.11.2017).
} 


\section{Lata 1531-1534: ustawodawstwo Henryka VIII prowadzące do uchwalenia aktu o zwierzchnictwie}

Kiedy w I530 r. Henryk VIII nabrał przekonania, że nie uzyska papieskiego orzeczenia stwierdzającego nieważność jego małżeństwa, zdecydował się zwołać w lutym następnego roku synod duchowieństwa do Canterbury. Specyfiką synodów zwoływanych w Anglii w okresie pełnego średniowiecza i wczesnej nowożytności były obrady prowadzone na wzór angielskiego parlamentu, z podziałem na izbę wyższą, w której zasiadali biskupi, i izbę niższą zrzeszającą ogół duchowieństwa. Udało się wówczas Henrykowi wymóc na zgromadzonych przyjęcie formuły mówiącej, że król jest jedynym protektorem i panem oraz najwyższym przewodnikiem Kościoła i duchowieństwa angielskiego. Jednak wobec sprzeciwu części zgromadzenia uchwalono również, że do powyższych słów dodaje się stwierdzenie, iż owe „Zwierzchnictwo” ograniczone jest prawem Chrystusowym² ${ }^{26}$. Tym sposobem król Anglii zrobił pierwszy poważny krok ku temu, aby ogłosić siebie „angielskim papieżem”. Dodatkowo na obydwie prowincje kościelne w Anglii król nałożył łącznie prawie I20 tys. funtów kary za naruszenie norm z zakresu prerogatyw praemunire ${ }^{27}$. Nałożenie kary tłumaczono w ten sposób, iż duchowieństwo popełniło przestępstwo, działając na szkodę królestwa Anglii poprzez przyznanie racji papieskiej opinii dotyczącej ważności małżeństwa Henryka i Katarzyny ${ }^{28}$. Rok później król postanowił jeszcze bardziej nagiąć hierarchię kościelną w Anglii do swojej woli. The Submission of the Clergy (Akt o podporzadkowaniu duchowieństwa) był wyrazem utraty zaufania do angielskiego duchowieństwa. Dokument stanowił, że tylko król może zwoływać przyszłe synody, a także, że wszystkie uchwały, jakie zostaną na nich podjęte, wymagają jego akceptacji. Nadto ustawa polecała również zbadanie obowiązujących już uchwał synodalnych pod kątem wierności królowi ${ }^{29}$. Henryk swoje działania uzasadniał treścią przysięgi, jaką podczas konsekracji składają biskupi, a która dotyczy posłuszeństwa papieżowi. Odnosząc się do tego, miał powiedzieć: „Myśleliśmy, że duchowni naszego królestwa są wyłącznie naszymi poddanymi, lecz teraz przekonaliśmy się, że są naszymi poddanymi tylko połowicznie, a co gorzej prawie nimi nie są"30.

Kolejnym posunięciem uzależniającym angielskie duchowieństwo katolickie od króla Anglii był Act in Restraint of Appeals (Akt o wstrzymaniu apelacji), uchwalony w marcu I533 r., który anulował możliwość odwoływania się w sprawach sądowych do papieża. Ponadto w pierwszym punkcie zapisane było stwierdzenie, że „królestwo Anglii, uznawane na świecie przez wiele dawnych kronik za imperium, [...] jest rządzone przez króla, któremu wszyscy poddani winni oddawać należną cześć i posłuszeństwo zaraz po Bogu"3i. Ustawa ta dała podwaliny pod inną, uchwaloną rok później - Act for the Submission of the Clergy ond Restraint of Appeals (Akt o podporzadkowaniu duchowieństwa i wstrzymaniu apelacji), która powtarzała punkty zawarte w dwóch poprzednich dokumentach. Dodatkowo akt ten

\footnotetext{
26 P. Hughes, The Reformation in England, t. 1, London 1963, s. 219; S. Lehmberg, The Reformation Parliament 1529-1534, Cambridge 1970, s. 114.

27 Praemunire - prawo mówiące o tym, że papież nie może naruszać praw przynależnych królowi angielskiemu w zakresie przyznawania duchowieństwu beneficjów.

28 Act for the Pardon of Clergy, w: G. Bray, Documents of the English Reformation 1526-1701, Cambridge 1994, s. 41.

29 The Submission of the Clergy, w: G. Bray, op. cit., s. 71.

30 Cyt. za.: J.M. Todd, Reformacja, tłum. J. S. Łoś, Warszawa 1974, s. 269.

31 Act in Restraint of Appeals, Par. 1, w: G. Bray, op. cit., s. 78, thumaczenie własne.
} 
stanowił, że synody duchowieństwa nie posiadają suwerenności w kwestiach prawodawczych. Oznaczało to, że wszystkie uchwały, jakie miano odtąd podejmować, miały być narzucane odgórnie przez króla. Akt ten ustanawiał również kary, jakie miały obowiązywać za nieuznawanie króla Anglii za najwyższą instancję w sprawach dotyczących Kościoła Anglii, oraz nadawał wymóg składania przez każdego duchownego przysięgi dotyczącej stosowania się do zapisów wyżej wymienionej ustawy ${ }^{32}$. Utworzono w ten sposób podwaliny pod oderwanie katolickiej Anglii od Rzymu. Stało się to wszystko za aprobatą ówczesnego biskupa Canterbury, którym w I532 r. został mianowany Tomasz Cranmer, oraz przy milczącej zgodzie większości duchowieństwa.

W styczniu I533 r. Henryk VIII wziął ślub ze swoją ówczesną faworytą, Anną Boleyn33, spodziewającą się już prawdopodobnie królewskiego dziecka. Szukając rozwiązania powstałej sytuacji, król zlecił Cranmerowi unieważnienie poprzedniego małżeństwa, co ten posłusznie uczynił w maju, korzystając z przepisów, które zawierały nowe ustawy dotyczące Kościoła w Anglii. W trakcie obrad powołanej specjalnie w tym celu komisji biskupów odebrano Katarzynie Aragońskiej miano królowej, jej córce zaś prawo dziedziczenia angielskiego tronu. Na odpowiedź Rzymu nie trzeba było zbyt długo czekać, gdyż II VII I533 r. papież Klemens VII ${ }^{34}$ uznał małżeństwo z Anną za nieważne. Papież powstrzymał się jednak przed nałożeniem na króla angielskiego ekskomuniki, co uczynił dopiero jego następca Paweł III ${ }^{35}$. Finał ,wielkiej sprawy” króla zakończył się ostatecznie w listopadzie I534 r., kiedy to parlament uroczyście uchwalił Act of Supremacy (Akt o zwierzchnictwie). Stwierdzał on, że „król Anglii oraz jego następcy będą uznawani za głowę Kościoła Anglii, co wynika z tradycji, a przez tę ustawę jest jedynie potwierdzone" ${ }^{6}$. Wydaje się jednak, że pozycja, jaką uzyskał Henryk VIII, a raczej prerogatywy z nią związane, miały bardziej charakter opieki nad Kościołem państwowym niż rzeczywistego pełnienia roli jego przywódcy w znaczeniu takim, jak rozumie się rolę papieża. Potwierdzeniem tej tezy jest uchwalony w tym samym roku The Ecclesiastical Licenses Act (Akt o licencjach kościelnych), który w drugim paragrafie nadawał arcybiskupowi Canterbury szereg uprawnień przynależnych dotąd papieżowi, wśród których najważniejszym było udzielanie dyspens ${ }^{37}$. Król nie rościł sobie prawa do sprawowania sakramentów, ani konsekrowania biskupów, lecz pozostawił we własnej gestii możliwość wizytacji kleru w parafiach i zakonach, dyscyplinowanie go, stanowienie prawa kanonicznego, sprawowanie sądu nad odszczepieńcami oraz korygowania opinii wyrażanych przez kaznodziejów głoszących słowo Boże ${ }^{38}$.

\footnotetext{
32 Act for the Submission of the Clergy and Restraint of Appeals, w: G. Bray, op. cit., s. 84-88; A.G. Dickens, The English Reformation, Glasgow 1967, s. 170.

33 Anna Boleyn (1501-1536) - córka Tomasza Boleyna i Elżbiety Howard; kochanka, a następne małżonka Henryka VIII. Królowa Anglii w latach 1533-1536.

34 Klemens VII (1478-1534) - właściwie Juliusz Medyceusz; papież w latach 1523-1534.

35 Paweł III (1468-1549) - właściwie Aleksander Farnesse; papież w latach 1534-1549.

36 The Act of the Supremacy, w: G. Bray, op. cit., s. 114, tłumaczenie własne.

37 The Ecclesiastical Licenses Act, w: G. Bray, op. cit., s. 96.

38 A.G. Dickens, The English Reformation, op. cit., s. 171.
} 


\section{Podsumowanie}

Powyższe rozważania dowodzą, że akt supremacji wydany przez Henryka VIII wynikał nie tylko z osobistych pobudek, ale był posunięciem głęboko zakorzenionym w angielskiej „tradycji” związanej z ideą wzajemnych relacji pomiędzy władzą świecką a Kościołem katolickim, istniejących już w okresie średniowiecza. Prawnicy zajmujący się tą kwestią od strony formalnej mieli niezwykle bogaty materiał prawny umożliwiający odłączenie się od Rzymu, niemal bez sprzeciwu, duchowieństwa angielskiego. Powstały w wyniku tych działań angielski Kościół państwowy stał się Kościołem schizmatyckim. Żadna z uchwalonych przez parlament ustaw reformacyjnych nie zmieniała bowiem dogmatów wiary katolickiej ani praktyki liturgicznej, jak miało to miejsce w państwach niemieckich przyjmujących luterańską formę chrześcijaństwa.

\section{Historical and legal conditions for Henry VIII's creation of the English State Church in 1534 \\ Summary}

The origins of the reformation in England are inseparably join to king Henry VIII. This character works in common human imagination is a bloody tyrant, who strives to satisfy his desires and ambitions. In a certain sense, his character traits affected his decisions. It is important to write, that the history of England abounds many examples of kings, who wants to got domination on church. In this article author by the analysis of medieval English law and other historical conditions, presents his thesis as an introduction to passing The Act of Supremacy in I534.

Keywords: Henry VIII, medieval England, The Act of Supremacy, reformation, the Catholic church

\section{BIBLIOGRAFIA}

\section{Źródła}

Act for the Pardon of Clergy I53I, w: G. Bray, Documents of the English Reformation I526I70I, Cambridge I994, s. 4I-5I.

Act for the Submission of the Clergy and Restraint of Appeals I534, w: G. Bray, Documents of the English Reformation 1526-I70I, Cambridge 1994, s. 84-88.

Act in Restraint of Appeals I533, w: G. Bray, Documents of the English Reformation I526I70I, Cambridge I994, s. 78-83.

Magna Carta, The Great Charter of English liberty granted (under considerable duress) by King John at Runnymede on June I5, I2I5, http://www.britannia.com/history/docs/ magna2.html (dostęp: I2.II.20I7).

The Ecclesiastical Licenses Act I534, w: G. Bray, Documents of the English Reformation I526-I70I, Cambridge I994, s. 94-I08.

The Submission of the Clergy 1532, w: G. Bray, Documents of the English Reformation I526I70I, Cambridge I994, s. 7I-72. 
Opracowania

Barber R., The Devil's Crown. A History of Henry II and His Sons, Conshohocken 1996.

Dahmus J.H., Richard II and the Church, „Catholic Historical Review”, 39/I954, s. 408-433.

Dickens A.G., The English Reformation, Glasgow 1967.

Dugmore C. W., The Mass and the English Reformers, London 1958.

The Oxford Dictionary of the Christian Church, edited by F. L. Cross, E. A. Livingstone, Current Online Version 2009, http:/www.oxfordreference.com/view/Io.Io93/ acref/9780192802903.00I.000I/acref-9780I92802903 (dostęp: I4.II.20I7).

Hughes Ph., The Reformation in England, t. I, London 1963.

Knowles M.D., Obolensky D., Historia Kościoła, t. 2, tłum. R. Turzyński, Warszawa I988, S. $155-\mathrm{I} 56$.

Kumor B., Historia Kościoła, t. 2: Wczesne średniowiecze chrześcijańskie, Lublin 2003.

Kumor B., Historia Kościoła, t. 3: Złoty okres średniowiecza chrześcijańskiego, Lublin 2005.

Kumor B., Historia Kościoła, t. 5: Czasy nowożytne. Rozłam w chrześcijaństwie zachodnim, Lublin 2004.

Lehmberg S., The Reformation Parliament 1529-I534, Cambridge 1970.

Moorman J.R.H., The History of the Church in England, Harrisburg I980.

Todd J.M., Reformacja, tłum. J. S. Łoś, Warszawa 1974. 